\title{
Spatial Model Environmental Insightful of City Manado
}

\author{
Usman Musa Sjahrain $^{1}$, Marjono $^{2}$, Bagyo Yanuwiadi ${ }^{3}$, Fadillah Putra ${ }^{4}$ \\ \{usmansjahrain69@gmail.com¹,marjono@ub.ac.id ${ }^{2}$, yanuwiadi60@yahoo.co.id ${ }^{3}$, \\ fadillahputra@ub.ac.id $\left.{ }^{4}\right\}$ \\ Universitas Brawijaya, Indonesia ${ }^{1,2,3,4}$
}

\begin{abstract}
Environmentally insight city planning is one of City Manado government planning programs in realizing a natural spatial city layout, aiming to prevent damage to the natural environment and become an environmentally insightful city area with natural nuances, so that the community feels comfortable and prosperous. In implementing the spatial planning of City Manado covering the activities of settings, coaching, implementing, and supervision in accordance with statutory regulations and various technical guidelines. Data on the spatial area of City Manado by $157.26 \mathrm{Km}^{2}$, the population is 431,880 people and the population density reaches 2,740 people $/ \mathrm{Km}^{2}$. The results multiple linear regression analysis and multiple correlation analysis simultan eously state that the spatial model of spatial plan and spatial utilization simultan of very significant effect the environment of City Manado by 81.72 percent. The results of simple linear regression analysis and partial correlation analysis separately state that the spatial model of the spatial plan separately of very significant effect the environment of City Manado by 12.06 percent. The results of simple linear regression analysis and partial correlation analysis separately state that the model spatial from spatial utilization separately of very significant effect the environment of City Manado by 76.21 percent. Manado City Government has carried out several stages the spatial of it environmental insightful is a the basic concepts of development that harmonize development with efforts to prevent environmental damage, in order a ensure the preservation of environmental functions.
\end{abstract}

Keywords: Spatial Model, Environment.

\section{Introduction}

In the national development planning system and spatial planning emphasizes the process of determining appropriate future actions through a sequence of choices (priorities) in a hierarchical manner taking into account available resources. The spatial planning process can be explained by a systems approach that involves inputs, processes and outputs (Direktorat Jenderal Penataan Ruang, 2006)..

Spatial according to Law number 26 of 2007 concerning Spatial Article 3: The implementation of spatial planning aims to realize a national territory that is safe, comfortable, productive, and sustainable based on the Archipelagic Insight and National Resilience with : a) the a) the realized of harmony between the natural environment and the artificial environment; b) the realized of cohesiveness in the use of natural resources and artificial resources by taking into account human resources; and c) the realized the protection of spatial functions and prevention of negative impacts on the environment due to spatial use.

In SNI 03-1733-2004 concerning Procedures for Housing Environmental Planning in Urban: 3.2.1. Urban planning the drafting activities of city plans, or and the review activities of existing 
city plans to be adapted to the conditions and situations needs of city developing that develops, 3.2.2. City plan, a plan drawn up in the framework of arrangement utilization of urban space in the framework regulating the administration of the city government (Standar Nasional Indonesia SNI 03-1733-2004 tentang Tata Cara Perencanaan Lingkungan Perumahan di Kota-kota, No.3.2.1.).

Manado City a one of the cities in Indonesia which is located in a coastal area with an all activities and settlements, accompanied by development growth very rapidly, causing population pressure with dynamics socio economic experience the enhancement. In implementing the spatial planning of City Manado covering the activities of settings, coaching, implementing, and supervising the spatial, necessary done drafting, synchronize, and socialize the legislation regulation the implementation and various technical guidelines.

\section{Research Methods}

\subsection{Research Methodology Approach}

In this study the authors used a research approach to the survey method and in its implementation the authors plunged directly into the study site by means of questionnaires and observations. Survey research is research that collects data on the variables studied [1].

The survey is defined as a method for collecting primary data based on sample data that is primary data and secondary data collected in a manner directly at the time the research is being carried out. The survey was conducted to obtain primary data by means of a questionnaire and while secondary data through observation [2].

\subsection{Method of Collecting Data}

Observation or direct observation is the activity of collecting data by conducting direct research on the condition of the environment of the research object that supports research activities, so that a clear picture of the condition of the object is obtained [3]. Data obtained from observations direct are secondary data, in general secondary data it used to provide additional and supplementary images which are further processed are presented in the form of tables or diagrams.

Questionnaire as of collection data of research the on certain conditions possibility not require the presence of researchers. Researcher's questions and respondents' answers can be put forward forward in writing through a questionnaire, In this study, the questionnaire was used to obtain primary data way by making a list of questions delivered to respondents to be filled with answers freely. Question the is in accordance with the research variable-variables or the object under study $[1]$.

\subsection{Definition of Variable Operations}

\subsubsection{Spatial Model (X)}

a) Spatial Plan (X1)

Spatial plan of arranged with perspective towards the expected future, starting from data, information, science, and technology that can be used. And pay attention to the diversity of insight into activities in each sector. The development of society and the environment And pay attention to the diversity of insight into activities in each sector. The development of society and the 
environment a life takes place dynamically [4]. Law number 26 of 2007 concerning Spatial, article 65: (1). The Implementation of spatial of spatial is carried out by the government involving the role of the community. (2) the role of the community in spatial as referred to in paragraph (1) shall be carried out, inter alia, through: a. participation in of spatial the drafting; b. participation in spatial the use; and c. participation in controlling spatial use.

The regional spatial plan is inseparable from the environmental concept which implies that every development activity must get be accountable its management and handling, so that the form of the regional spatial plan implemented by the regional government in turn becomes a logical consequence for the public to understand the importance of the regional spatial plan and the importance of boundaries regarding spatial which are closely related to the nuances of the implementation of government which are demanded to meet the needs of the community and regulate the pattern of scope in carry out daily activities [5].

\section{b) Spatial Utilization (X2)}

Spatial utilization is a series of program of activities out carrying the development that utilize space according to a specified time period specified in the spatial plan. Spatial utilization is carried out in stages through the preparation of development implementation program activities related to the spatial utilization to be carried out by the government and the community, both individually and jointly in accordance with the established spatial plans [4].

Act number 26 of 2007 concerning Spatial Plan, Article 1, (14). Utilization Space is an effort to realize the spatial structure and spatial pattern in accordance with the spatial plan through compilation and the implementation of the program and its financing, (15).Control of spatial use is an effort to realize orderly spatial. The Spatial utilization gives the following meanings: 1 ). The patterns of management of land utilization, water utilization, air utilization and other source utilization are in accordance with the principle of regional spatial plan. 2). All provisions regarding the patterns of management of land utilization, water utilization, air utilization, other utilization must be regulated by the state and realized in accordance with government regulations [6].

\section{c) The Environment $(\mathrm{Y})$}

The life environment is a unity of space with all thing and living creatures, including in it man and their behavior. The environmental components consist of abiotic factors (soil, water, air, weather, temperature) and biotic factors (plants and animals, including humans). The life environment both biotic and abiotic factors influential and influenced by humans. Everything in the environment can be exploited by humans to the ends needs of human life, because the environment has the carrying capacity [7].

Law number 32 of 2009 concerning Living Environment Protection and Management, article 1, (1). The Living Environment is a unity of space with all objects, power, state, and living things, including humans and their behavior, which affect nature itself, the continuity of life, and the wellbeing of humans and other living creatures. (8) The Environmental capacity of life is the ability of the environment of life to absorb substances, energy, and / or other components that enter or are incorporated into it.

Regulation of the Minister Country of Environment No. 09 of 2011 concerning the Guidelines for Strategic Environment Assessment, General Definition as follows: 21). Life environment capacity is the ability of the life environmental to absorb substances, energy, and/or other components that enter or are incorporated into it. Environmental management is carried out with the principles of State responsibility, the principle of sustainability, and the principle of benefits to 
realize sustainable development that is environmentally sound in order of Indonesian human. The life environmental capacity is the ability of life environment to absorb substances, energy, or other components that enter or are incorporated into it, Capacity is regulated in Government Regulations Provisions regarding the quality standards of environmental damage, prevention and damage countermeasures. and the restoration of carrying capacity is regulated by Government Regulation [7].

\subsection{Population and Sample}

Population is a generalization area that consists of subjects or objects with certain qualities and characteristics determined by researchers, while the sample is part of the number and characteristics possessed by the population [1]. In this study, the population is the overall of large area data by $157.26 \mathrm{Km}^{2}$, amount population of by 431,880 people and the population density by 2,740 inhabitants $/ \mathrm{Km}^{2}$ spread over 11 (Eleven) Districts, namely: Malalayang, Sario, Wanea, Wenang, Tikala, Paal Dua, Mapanget, Singkil, Tuminting, Bunaken and Bunaken Islands [8].

The sample is a some members of the population studied, the sample taken from the population must be truly representative (representing), namely Mapanget subdistrict of large area $47.76 \mathrm{Km}^{2}$ and the amount population on 17 years old and older by 40,433 people. To determine the sample that will be used in this study with Probability sampling technique is a sampling technique that provides equal opportunities for each element (member) of the population to be selected as a sample member, with the technique that is Simple random sampling [9]. To determine the sample size, if of number of subjects is greater than 100 soul of respondents then the number of subjects taken $10-50 \%$. For this study, samples can be taken of $50 \%$ of the population of 50 soul of respondents in Mapanget sub district city Manado [9].

\subsection{Data Analysis}

\subsubsection{Hypothesis Data Analysis 1}

To analyze the extent of the influence of the model spatial (X) of spatial plan (X1) and spatial utilization (X2) simultan of very significant effect the environment (Y) of City Manado.

For data analysis hypothesis 1 , namely:

- Multiple linear regression analysis. This analysis is used to find out how much influence X variables consisting of $\mathrm{X} 1$ and $\mathrm{X} 2$ simultan to the variable $\mathrm{Y}$.

Multiple linear regression equation [10].

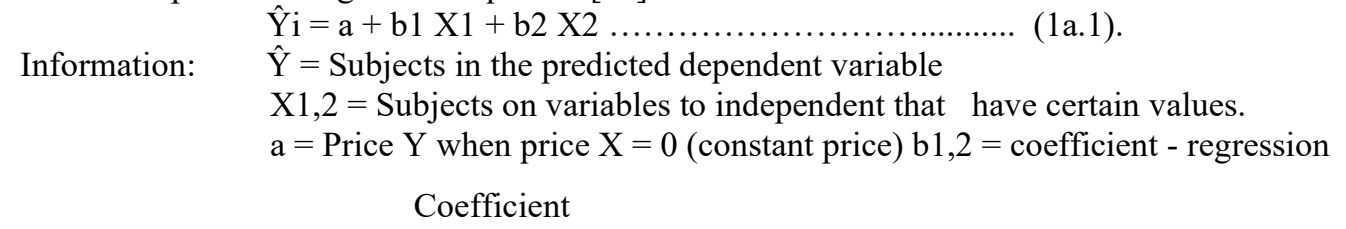

\section{Coefficient}

The Statistical F the significant test of multiple regressions [10].

$$
\mathrm{Fi}=\frac{J K_{r e g} / k}{J K_{r e s} / d k}
$$

Information: $\quad \mathrm{F}=$ significant test of multiple regression

JKreg $=$ Number of squares - squares the regression 


\section{$J$ Kres $=$ Number of squares - squares the residual $\mathrm{dk}=$ Degree of Freedom $(\mathrm{n}-\mathrm{k}-1)$ \\ $\mathrm{k}=$ the number of independent variables $\mathrm{X}$}

- Multiple correlation analysis. This analysis is used to measure the magnitude of influence of variables $\mathrm{X}$ consisting of $\mathrm{X} 1$ and $\mathrm{X} 2$ simultan to the variable $\mathrm{Y}$.

The coefficient of multiple determination [11].

$$
\mathrm{R}^{2} \mathrm{i}=\frac{J K_{r e g}}{\sum Y i^{2}}
$$

Information: $\quad \mathrm{R}^{2} \mathrm{i}=$ The coefficient of multiple determination

$J K=$ Number of squares - squares the regression

$\Sigma Y i^{2}=$ Number of square - squares the total

The statistic $t$ the coefficient test of multiple correlation [10].

$$
\mathrm{ti}=\frac{b i}{S a i}
$$

Information:

$\mathrm{ti}=$ test of multiple correlation coefficients, $\mathrm{ti}=\mathrm{t} 1$ and $\mathrm{t} 2, \mathrm{Sai}=$ coefficient standard error, $\mathrm{Sai}=\mathrm{Sa} 1$, and $\mathrm{Sa} 2$

$b i=$ Coefficients - coefficients, $b 1$ and $b 2$

\subsubsection{Hypothesis Data Analysis 2}

To analyze the extent of the influence of the spatial model (X) of spatial plan (X1) and spatial utilization (X2) separately to the environment (Y) of City Manado.

For data analysis hypothesis 2 , namely:

- Simple linear regression analysis. This analysis is used to find out how much influence each $\mathrm{X}$ consists of $\mathrm{X} 1$ if $\mathrm{X} 2$ remains, separately against variable $\mathrm{Y}$.

Simple linear regression equation [11].

$$
\begin{aligned}
& \hat{\mathrm{Y}} \mathrm{i}=\mathrm{a}+\mathrm{bi} \mathrm{Xi} \ldots \ldots \ldots \ldots \ldots \ldots \\
& \text { Information: } \hat{\mathrm{Y}} \mathrm{i}=\text { Subjects in the predicted dependent variable } \\
& \mathrm{X}=\text { Subjects on variables to independent that have certain values } \\
& \mathrm{a}=\text { Price } \mathrm{Y} \text { when price } \mathrm{X}=0 \text { (Constant Price) } \mathrm{b}=\text { Regression coefficient }
\end{aligned}
$$

The statistical F the test independent of simple regression (List of Analysis of Variance) [10].

$$
\mathrm{Fi}=\frac{S_{r e g}^{2}}{S 2_{\text {res }}}
$$

Information: $\quad \mathrm{F}=$ simple regression independent test $S^{2}$ reg = Regression variance $S^{2}$ res = Residual variance

- Partial correlation analysis. This analysis is used to measure the magnitude of the effect of each $\mathrm{X}$ consisting of $\mathrm{X} 1$ if $\mathrm{X} 2$ remains, separately against variable $\mathrm{Y}$.

Partial correlation coefficient [11]. 


$$
\text { ry1.2 }=\frac{r y 1 .-r y 2 . . r 1.2 .}{\sqrt{\left(1-r^{2} y 2 .\right)\left(1-r^{2} 1.2 .\right)}}
$$

Information

ry1.2 $=$ Partial correlation coefficient

ry $1=$ ry $2=$ the coefficient of partial determination

The statistic $t$ the coefficient test of partial correlation [11].

$$
\mathrm{ti}=\frac{r y 1.2 \sqrt{n-2}}{\sqrt{1-r^{2} y 1.2}}
$$

Information: $\quad \mathrm{t} i=$ test partial correlation coefficient, $\mathrm{t} i=\mathrm{t} 1$ and $\mathrm{t} 2$ ry1.2 $=$ Partial correlation coefficient

\section{Results and Discussion}

\subsection{Spatial Description}

Spatial area data of City Manado by $157.26 \mathrm{Km}^{2}$, population is 431,880 people and he population density reaches 2,740 people $/ \mathrm{Km}^{2}$ which are spread in 11 (Eleven) Subdistricts, namely: Malalayang, Sario, Wanea, Wenang, Tikala, Paal Dua, Mapanget, Singkil, Tuminting, Bunaken and Bunaken Islands [8].

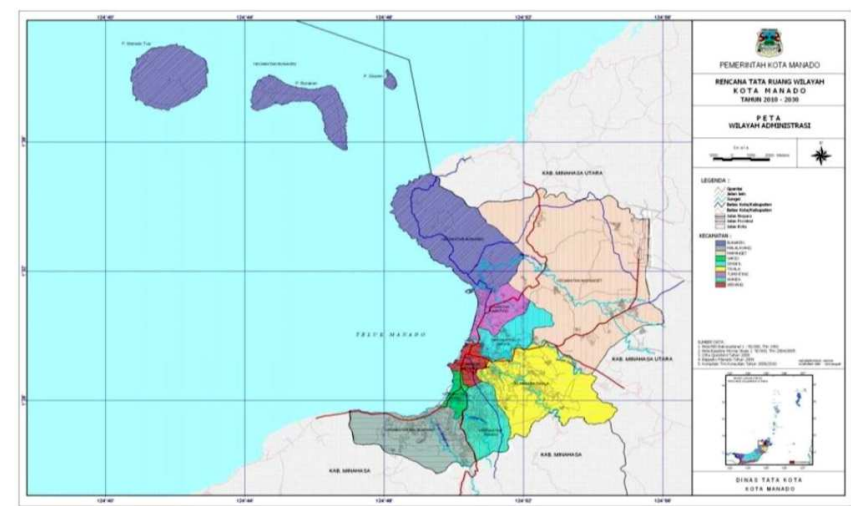

Fig. 1. Spatial Map of City Manado (Manado City in data 2019).

SNI 03-1733-2004 concerning Procedures for Housing Environmental Planning in Urban: 3.2.3 environmental arrangement of an effort to improve, change, and rearrange the environment certain suit the principle of optimal spatial utilization.

3.2.4 Regional Spatial Plan (RTRW) strategy and direction of wisdom the region spatial utilization, which includes structure and patterns use region, as well as criteria and management patterns.

Topography is study or the detailed decomposition the about the advance state of the earth on area, such as the location of latitude and longitude, slope, altitude, and contour of the soil, climate is the state of the weather average on region in period of time long relatively. 


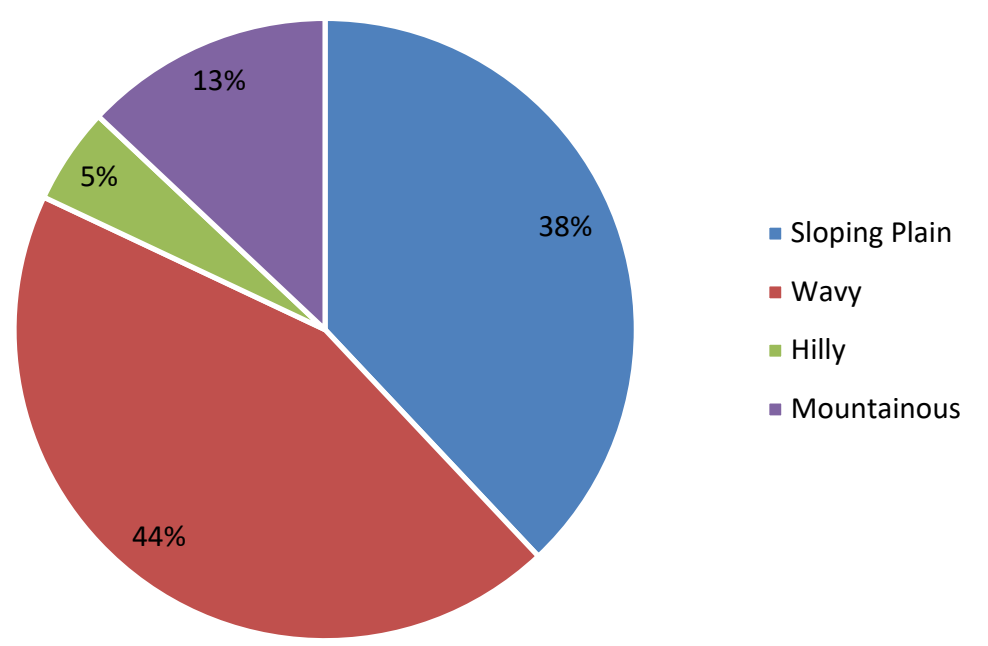

Fig. 2. Area Topography of City Manado (Manado City in data 2019).

\subsection{State of the environment}

The condition of the environmental with all the diversity of interactions that exist is able to balance the situation. But it is also possible, such conditions can change by human intervention with all the activities that fulfill the needs that sometimes exceed the limits of the environment can naturally take place.

Manado City Regional Regulation Number 01 of 2014 concerning City Manado Regional Plan for 2014 - 2034 Article 1, (36). Ecosystem is the order of life environmental element which constitutes intact unity, comprehensive and influence each other in forming the life environmental balance, stability and productivity. (40). The life environmental Capability is the ability of the life environment to absorb substances, energy and / or other components that enter or are incorporated into it.

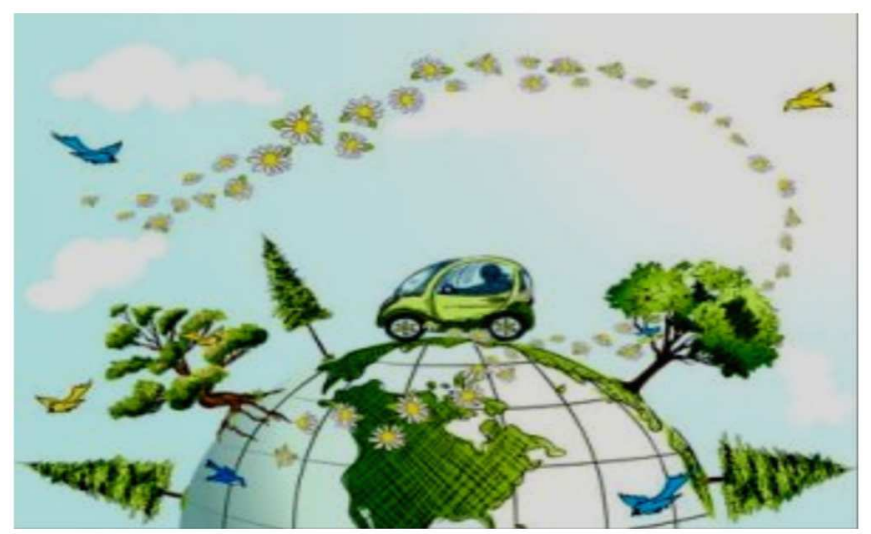

Fig. 3. State of the environment (Environmental Guidelines, 2019). 


\subsection{Hypothesis Analysis Results 1}

Corresponding of field observations and initial surveys it is suspected the influence of structuring models space (X) of spatial plan (X1) and spatial utilization (X2) simultan of very significant effect the environment $(\mathrm{Y})$ of City Manado (Hypothesis 1). The results of the multiple linear regression analysis regarding the relationship between the research variable are stated in the following equation : $\hat{Y}=-0.017+0.143 \mathrm{X} 1+0.857 \mathrm{X} 2$.

Table 1. Results Analysis of Spatial Model (X) and Environment (Y)

\begin{tabular}{|c|c|c|c|c|}
\hline \multirow{2}{*}{$\begin{array}{c}\text { No. } \\
1 .\end{array}$} & \multirow{2}{*}{\begin{tabular}{l}
\multicolumn{1}{c}{ Analysis } \\
Variables X and Y \\
Multiple Linear Regression : \\
Environmental (Y)
\end{tabular}} & \multicolumn{3}{|c|}{ Hypothesis Analysis Results 1} \\
\hline & & Koef. a & Koef. b & Fhit \\
\hline & $\begin{array}{l}\text { Spatial Plan (X1) } \\
\text { Spatial Utilization (X2) }\end{array}$ & $-0,017$ & $\begin{array}{l}0,143 \\
0,857\end{array}$ & $48,83^{*}$ \\
\hline 2. & $\begin{array}{l}\text { Multiple Correlation : } \\
\text { Environmental (Y) }\end{array}$ & $\mathrm{R} i$ & $\mathrm{R}^{2} i$ & thit \\
\hline & $\begin{array}{l}\text { Spatial Plan (X1) } \\
\text { Spatial Utilization (X2) }\end{array}$ & 0,9040 & 0,8172 & $\begin{array}{l}0,65 \\
4,47 *\end{array}$ \\
\hline
\end{tabular}

(Processed data, 2019)

Note

1. $\mathrm{F}_{\text {daf }}=0,05(2,27)=3,35$

2. $t_{\text {daf }}=(0,975)=2,05$

* = Relationships are Very Significant

Hypothesis 1 data analysis results, the results of the multiple linear regression analysis table 1 , show the results of the test independent the multiple regression of states that the spatial model (X) of the spatial plan (X1) and space utilization (X2) simultan of very significant effect the environment (Y) of City Manado. This conformity is proven by statistic F test independen par: $\mathrm{F} 1$ hit $=48.83>\mathrm{Fdaf}=3.35, \mathrm{H} 1$ hypothesis accepted at the real level $\alpha=0.05$ or $5 \%$ gives a very significant influence. The results of the multiple correlation analysis table 1 , show coefficient of multiple determination: $\mathrm{R} 12=0.8172$ or 81.72 percent, states that the model spatial $(\mathrm{X})$ of the spatial plan (X1) and space utilization (X2) simultan of very significant effect the environment (Y) of City Manado. The conclusion that the model spatial of the spatial plan and spatial utilization simultan of very significant effect the environment of City Manado by 81.72 percent.

\subsection{Hypothesis Analysis Results 2}

To determine the significan level of influence of the model spatial (X) of the spatial plan (X1) and spatial utilization (X2) separately to the environment (Y) (Hypothesis 2.) For more details then of below this the explained meaning of influence each in the spatial plan model (X) is explained below. Hypothesis 2 data analysis results, as follows:

\subsubsection{Spatial Planning (X1)}

The model spatial (X) of the spatial plan (X1) separately of very significant effect the environment $(\mathrm{Y})$ of Manado City. The results of simple linear regression analysis regarding the 
relationship between research variables are expressed in the following equation : $\hat{Y}=1.802+$ $0.868 \mathrm{X} 1$. The results simple linear regression analysis table 2, the show results the test independent simple regression states that the model spatial (X) of the spatial plan (X1) separately of very significant effect the environment $(\mathrm{Y})$ of City Manado. This conformity is proven by statistic $\mathrm{F}$ test independen simple $: \mathrm{F} 12 \mathrm{hit}=0.85>\mathrm{Fdaf}=0.24$, $\mathrm{H} 1$ hypothesis is accepted at the real level $\alpha=0.05$ or $5 \%$ gives a very significant influence. The results partial correlation analysis of table 2, show coefficient partial determination : $\mathrm{r}^{2} \mathrm{y} 1.2=0.1206$ or 12.06 percent, states that the model spatial (X) of the spatial plan (X1) separately of very significant effect the environment $(\mathrm{Y})$ of City Manado. The conclusion that the model spatial of the spatial plan separately of very significant effect the environment of City Manado by 12.06 percent.

Table 2. Results Analysis of Spatial Model (X) and Environment ( $\mathrm{Y}$ )

\begin{tabular}{|c|c|c|c|c|}
\hline \multirow{2}{*}{$\begin{array}{c}\text { No. } \\
1 .\end{array}$} & \multirow{2}{*}{\begin{tabular}{l}
\multicolumn{1}{c}{ Analysis } \\
Variables X and Y \\
Simple Linear Regression : \\
Environmental $(\mathrm{Y})$
\end{tabular}} & \multicolumn{3}{|c|}{ Hypothesis Analysis Results 2} \\
\hline & & Koef. a & Koef. b & Fhit \\
\hline \multirow{5}{*}{2.} & Spatial Plan (X1) & 1,802 & 0,868 & $0,85^{*}$ \\
\hline & Spatial Utilization (X2) & 0,574 & 1,065 & $1,58^{*}$ \\
\hline & $\begin{array}{l}\text { Partial Correlation : } \\
\text { Environmental (Y) }\end{array}$ & ry $i$ & $\mathrm{r}^{2} \mathrm{y} i$ & t hit \\
\hline & Spatial Plan (X1) & 0,3473 & 0,1206 & 1,96 \\
\hline & Spatial Utilization (X2) & 0,8730 & 0,7621 & $9.47 *$ \\
\hline
\end{tabular}

(Processed data, 2019)

Note :

1. $\mathrm{F}_{\text {daf }}=0,95(1,28)=0,24$

2. $\quad \mathrm{t}_{\mathrm{daf}}=(0,975)=2,05$

* = Relationships are Very Significant

Spatial is an effort to realize the spatial plan by taking into account the state of the natural environment, the artificial environment, the social environment, interaction between the environment, stages and management of development, as well as and coaching institutional capabilities and human resources by basing on the unity of the national territory and at aimed big as - The magnitude of people's prosperity [12].

The increasing number of urban populations is a burden on the environment both the physical environment and the socio cultural and aesthetic environment. With pay attention to all constraints the, then the development managers both government and private, are expected is expected to be able to compile and doing something integrated work mechanism as well as including the participation of the community and law enforcement agencies are g city development the those with an environmental perspective [13].

\subsubsection{Space Utilization (X2)}

The model spatial (X) of the spatial utilization (X2) separately of very significant effect the environment (Y) of Manado City. The results of simple linear regression analysis regarding the relationship between research variables are expressed in the following equation: $\hat{Y}=0.574+1.065$ $\mathrm{X} 2$. The results simple linear regression analysis table 2, the show results the test independent simple regression states that the model spatial (X) from space utilization (X2) separately of very 
significant effect the environment $(\mathrm{Y})$ of City Manado. This conformity is proven by statistic $\mathrm{F}$ test independen simple: $\mathrm{F} 12 \mathrm{hit}=1,58>\mathrm{Fdaf}=0,24$, hypothesis is accepted at the real level $\alpha=0.05$ or $5 \%$ gives a very significant influence. The results partial correlation analysis table 2 , show coefficient partial determination: $\mathrm{r} 2 \mathrm{y} 2.1=0,7621$ atau 76,21 persen, states that the model spatial (X) from space utilization (X2) separately of very significant effect the environment (Y) City Manado. The conclusion that the model spatial of the spatial plan separately of very significant effect the environment of City Manado by 76,21 percent.

Law number 26 of 2007 concerning Spatial Planning (hereinafter referred to as UUPR). Spatial can guarantee all interests, that is, the interests of the government and the community fairly in the meaning of integrated means that spatial is analyzed and formulated into a single unit of various spatial use activities, both by the government and the community.

\section{Conclusion}

Based on the results and discussion above, the obtained then findings are: Environmentally insight city planning is one of the Manado City government planning programs in realizing a natural spatial city layout, aiming to prevent damage to the natural environment and become an environmentally insightful city area with natural nuances, so that the community feels comfortable and prosperous.

The results multiple linear regression analysis and multiple correlation analysis simultaneously state that the spatial model of spatial plan and spatial utilization simultan of very significant effect the environment of City Manado by 81.72 percent. The results of simple linear regression analysis and partial correlation analysis separately state that the spatial model of the spatial plan separately of very significant effect the environment of City Manado by 12.06 percent. The results of simple linear regression analysis and partial correlation analysis separately state that the model spatial from spatial utilization separately of very significant effect the environment of City Manado by 76.21 percent.

Manado City Government has carried out several stages the spatial of it environmental insightful is a the basic concepts of development that harmonize development with efforts to prevent environmental damage, in order a ensure the preservation of environmental functions.

\section{References}

[1] E. M. Sangadji, Metodologi Penelitian Pendekatan Praktis dalam Penelitian. Yogyakarta: CV. Andi Offset, 2010.

[2] D. Wibisono, Panduan untuk Tesis, Tesis dan Persiapan Disertasi. Yogyakarta: CV. Andi Offset, 2013.

[3] S. Siregar, Metode Penelitian Kuantitatif, 4th ed. Jakarta: Kencana, 2017.

[4] R. Mirsa, Elemen Perencanaan Tata Ruang Kota. Yogyakarta: Graha Ilmu, 2012.

[5] Nurhadi, Perencanaan Tata Ruang Kota. Bandung: Tarsito, 2002.

[6] Sugianto, Teori Hukum Tata Ruang. Jakarta: Rajawali Pers, 2004.

[7] Soemarno, Pedoman Umum untuk Menulis Artikel Jurnal Ilmiah. Malang: PPs Universitas Brawijaya, 2009.

[8] B. P. S. K. Manado, “Kota Manado Dalam Angka 2019," Manad. Badan Pus. Stat. Kota Manad., 2018.

[9] Sugiyono, Metode Penelitian Kuantitatif, Kualitatif dan R \& D Metode. Bandung: Alfabeta, 2017.

[10] Sugiyono, Statistics for Research. Yogyakarta: Alfabeta, 2017.

[11] A. Supangat, Statistics in the Study of Descriptive and Nonparametric Descriptions. Jakarta: 
Kencana, 2010.

[12] A. K. Mahi, Development of the Theory and Application Areas. Jakarta: Prenadamedia Group, 2018.

[13] R. Budi, Environmentally Friendly City. Jakarta: Pranada Media, 2004. 